\title{
Can plasma cholinesterase act as an adjuvant prognostic index in acute burn cases?
}

\author{
Yasmine Fikry $^{1}$, Amany Elsayed ${ }^{1}$, Mohamed Ahmed Sayed ${ }^{2}$, Dalia Nabil ${ }^{1}$ \\ ${ }^{1}$ Department of Forensic Medicine and Clinical Toxicology, Faculty of Medicine-Ain Shams University, Cairo Egypt. \\ ${ }^{2}$ Department of plastic, Maxillofacial and Burn Management, Faculty of Medicine-Ain Shams University, Cairo Egypt.
}

\begin{abstract}
Background: The importance of burn prognostic indices lies not only on the prediction of the outcome of an individual patient, but also on the distribution of the patients in comparable groups of severity for therapeutic purposes. Although the realistic prediction of the outcome of an individual patient is the first and main question of patient family, the quantitative measurement of a patient illness using these indices is of great importance for the burn center in deciding its therapeutic policy. The more accurate the indices, the more useful they are for the latter purpose for these reasons. Since several complications may occur after burn injury, some of them are fatal; the allegation of negligence may not be unusual. The patient relatives may claim that the death is the result of the improper management of the treating medical team rather than the unavoidable complications. Aim: This study aimed to assess the potential role of plasma cholinesterase as an adjuvant prognostic index in acutely burned patients to ascertain malpractice claims. Subjects and methods: A prospective study that was conducted on 40 cases (30 acute burned patients and 10 controls) in The Burn Unit at El Demerdash Hospital. Venous blood samples were collected from all cases under study in 1, 5, and 14 day post burn for measuring plasma cholinesterase, platelets, albumin and CRP. Results: there was significant difference between the control group and the acute burned group regarding the studied parameters except platelets concentration in day one sample. There was negative correlation between plasma cholinesterase, platelets, albumin and TBSA while positive correlation was found with CRP. There was significant difference between the survivors and non survivors regarding all studied parameters in day 1, 5 and 14 except for CRP only in day 5\&14 significant difference was noticed. Plasma cholinesterase sensitivity when it was measured alone was $100 \%$ in the different study periods, with CRP or albumin or collectively in day 5, 14. Conclusion: The current study concluded that plasma cholinesterase can be measured as a prognostic index alone with $100 \%$ sensitivity in day 1, 5 and 14 post burn. When it was measured adjuvant to platelets in day 1 sensitivity was $98 \%$, to CRP or albumin or both in day 5 and 14 , the sensitivity was $100 \%$. Recommendations: The present study recommended plasma cholinesterase to be measured as a routine clinical laboratory test for the admitted acutely burned patient.
\end{abstract}

Key words

Plasma cholinesterase, acute burn, albumin, platelets, CRP

\section{Introduction}

$\Lambda$ burn is a tissue injury from thermal application or from the absorption of physical energy or chemical contact (Nascimbeni et al., 2018). Millions of people around the world are hospitalized for the treatment of burn each year; the daily cost of care for a burn victim is tremendous. The economic loss to any nation is staggering. This includes painful and lengthy hospitalization, multiple stages of surgery, permanent disfigurement and disability, prolonged rehabilitation, loss of income and enormous financial burden on both the burn victims and community. Burn itself and its complications can lead to permanent changes in patient life and that of his family (Friedstat et al., 2017).

The importance of burn prognostic indices lies not only on the prediction of the outcome of an individual patient, but also on the distribution of the patients in comparable groups of severity for therapeutic purposes. Although the realistic prediction of the outcome of an individual patient is the first and main question of patient family, the quantitative measurement of a patient illness using these indices is of great importance for the burn center in deciding its therapeutic policy. The more accurate the index, the more useful it is for the latter purpose for these reasons (Nascimbeni et al., 2018).

Since several complications may occur after burn injury, some of them are fatal; the allegation of negligence may not be unusual (Nakache et al., 2011). The patient relatives may claim that the death is the result of the improper management of the treating medical team rather than the unavoidable complications (Snell et al., 2013). 
This allegation may arise also in homicidal deaths, when death in burnt victims occurred after duration of hospital admission. It is of great medico-legal importance in these cases to decide if the death was due to physician negligence or as an anticipated consequence of burn injury. This reveals the need for investigating predictors of mortality in cases of burn injuries that can be determined in early stage of burn before start of medical interventions to reflect severity of injury and body response to it (Aktas et al., 2018).

In addition, prediction of outcome for burnt patients is essential to support clinical decision making, improve overall patient management, alleviate individual suffering, minimize the complications and improve hospital resource allocation (Walczak and Velanovich, 2018).

\section{Aim of the Study}

As with any kind of malpractice issue, the question is whether the practitioner conduct or care deviated from the applicable standard of care or not?.

The aim of this study was to assess the potential role of plasma cholinesterase as an adjuvant prognostic index in acutely burned patients to ascertain malpractice claims.

\section{Patients and Methods}

Study design: A prospective study that was conducted in The Burn Unit at El Demerdash Hospital. The study included 40 cases, 1 st group included 30 patients those who were admitted to Burn Unit at El Demerdash Hospital and according to the outcome they were further classified into two subgroups survivors and non survivors, 2nd group included 10 persons of patient's relatives apparently healthy served as a control group. The cases who were selected to be included in the study are acutely adult burn patients of both sexes (20 males and 10 females) admitted within 24 hours of incidence, their age ranges from 18 to 45 who were exposed to thermal injury, total burn surface area ranges from 15 to $40 \%$ of body surface area and the depth was partial and full thickness burns. Exclusion criteria: patients with Chronic liver disease, organo phosphorus insecticides exposure, malignancy, obesity, extremes of age, diabetes mellitus, malnourishment, electrical and chemical burns, total burn surface area area $<15 \%$ or $>40 \%$,superficial dermal burns and erythema.

Ethical Considerations: Approval was taken from ethical committee Ain Shams University. Approval from Burn Unit general director was also taken. An informed written consent was taken from burned patients or their relatives and their information was anonymous for maintaining the confidentiality.

Five ml venous blood samples were collected from all cases under study in day 1,5 , and 14 postburn. Two ml blood was preserved with EDTA for measuring platelets concentration. The remaining blood samples were then centrifuged, the serum was then separated, and the levels of plasma cholinesterase, albumin and CRP were measured.

Statistical analysis: Data were collected, revised, coded and entered to the Statistical Package for Social Science (SPSS) version 23. The quantitative data were presented as mean, standard deviations, ranges and qualitative one was presented as number and percentages.

The comparison between two independent groups with quantitative data and parametric distribution were done by using Independent t-test.

The comparison between more than two paired groups with quantitative data and parametric distribution were done by using Repeated Measures ANOVA, test.

Spearman correlation coefficients were used to assess the correlation between two quantitative parameters in the same group.

The significance of p-value was considered as the following: P-value > 0.05: Non -significant, P-value < 0.05: Significant.

\section{Results}

The present study showed that the mean age of the studied burned cases was $29.20 \pm 8.08$ years and males constituted $66.7 \%$ and females $33.3 \%$.

Table (1): showed significant difference between acute burned cases and controls as regard plasma cholinesterase, albumin and CRP levels in day 1, on the other hand there was no significant difference as regards platelets concentration.

Table (2): showed significant difference between the acute burned group and controls as regards plasma cholinesterase at the different study periods, there is significant reduction in day 5 when compared with day 1 and there is an improvement in day 14 when compared with day 5.

As regards serum albumin level there was significant reduction in the level of day 5 and 14 when compared with day 1 .

As regards CRP there was significant increase in the level of CRP at different study periods when compared with control, significant increase in day 5, 14 when compared with day 1.

As regards platelets there was significant reduction in the level of day 5 when compared with day 1 and day 14 samples.

Table (3): showed negative correlation between plasma cholinesterase, albumin and platelets and total burn surface area in day 1, 5 and 14 and positive correlation between CRP and total burn surface area in day 5 and 14 only.

Table (4): showed that there was significant reduction in the levels of plasma cholinesterase, platelets, and albumin at the different study periods in non survivors burned patients when compared with survivors' subgroup. On the other hand, CRP level showed significant increase in day $5 \& 14$ in nonsurvivors 'subgroup. While in day 1, non-significant change was noticed.

Table (5): showed that there was negative correlation between plasma cholinesterase and TBSA in day 1 and 14 in survivors' group. On the other hand, Positive correlation between CRP and TBSA in day 1, 5 and 14 in survivors' group was observed. 
Table (6): showed the best cut off point for plasma cholinesterase, albumin, and CRP for differentiation between the acute burned cases and the control. For plasma cholinesterase was found $\leq 6223 \mathrm{u} / 1$ with sensitivity of $100 \%$, specificity of $90 \%$ and area under curve AUC of $96.3 \%$. For albumin the best cut off point was found $\leq 3.4 \mathrm{~g} / \mathrm{dl}$ with sensitivity of $53.33 \%$, specificity of $90 \%$ and AUC of 78.2, while CRP cut off point was found $>13 \mathrm{mg} / \mathrm{l}$ with sensitivity of $100 \%$, specificity of $100 \%$ and AUC of $100 \%$.

Table (7): showed that the best cut off point for plasma cholinesterase as a prognostic marker in day 1 was found $\leq 3320$ with sensitivity of $100 \%$, specificity of $100 \%$. In day 5 the best cut off point was found $\leq 2568$ with sensitivity of $100 \%$, specificity of $90.48 \%$. In day 14 the best cut off point was found $\leq 2214$ with sensitivity of $100 \%$ and specificity of $100 \%$.

Table (8): showed that the best cut off point for platelets as a prognostic marker in day 1 was found $\leq 310$ with sensitivity of $77.78 \%$, specificity of $66.67 \%$. In day 5 the best cut off point was found $\leq 149$ with sensitivity of $88.89 \%$, specificity of $100 \%$. In day 14 the best cut off point was found $\leq 350$ with sensitivity of $88.89 \%$ and specificity of $80.95 \%$.

Table (9): showed that the best cut off point for albumin as a prognostic marker in day 1 was found $\leq 3.3$ with sensitivity of $88.89 \%$, specificity of $66.67 \%$. In day 5 the best cut off point was found $\leq 2.3$ with sensitivity of $100 \%$, specificity of $80.95 \%$. In day 14 the best cut off point was found $\leq 2.2$ with sensitivity of $100 \%$ and specificity of $90.48 \%$.

Table (10): showed that the best cut off point for CRP in day 5 was found $>126$ with sensitivity of $100 \%$, specificity of $100 \%$, and in day 14 the best cut off point was found $>106$ with sensitivity of $100 \%$ and specificity of $100 \%$.

Table (11): showed Plasma cholinesterase sensitivity when measured with CRP, albumin \& platelets at different study periods in acute burned patients:

- In day 1 the plasma cholinesterase sensitivity was the highest when measured with platelets (98\%), it was the lowest when measured with CRP (50\%).

- In day 5 the plasma cholinesterase sensitivity was the highest (100\%) when measured with CRP or albumin and when measured with CRP and albumin collectively. It was the lowest when measured with platelets (94.5\%).

In day 14 the plasma cholinesterase sensitivity was the highest (100\%) when measured with CRP or albumin and when measured with CRP and albumin collectively. It was the lowest when measured with platelets $(94.5 \%)$.

Table (1): Student t test, comparison between control and acute burned groups as regards studied parameters

\begin{tabular}{|l|c|c|c|c|}
\hline \multirow{2}{*}{ Variables } & $\begin{array}{c}\text { Control group } \\
\text { No. }=\mathbf{1 0}\end{array}$ & $\begin{array}{c}\text { Acute burned group } \\
\text { No. }=\mathbf{3 0}\end{array}$ & \multirow{2}{*}{ t } & \multirow{2}{*}{ P } \\
\cline { 2 - 4 } & Mean \pm SD & Mean \pm SD & & \\
\hline Plasma cholinesterase(u/l) & $7692.00 \pm 1426.36$ & $3985.63 \pm 1263.07$ & 7.786 & 0.000 \\
\hline Platelets $\left(10^{3} / \mathrm{ll}\right)$ & $351.50 \pm 39.17$ & $315.47 \pm 64.49$ & 1.659 & 0.105 \\
\hline Albumin $(\mathrm{g} / \mathrm{dl})$ & $4.18 \pm 0.64$ & $3.36 \pm 0.77$ & 3.007 & 0.005 \\
\hline CRP $(\mathrm{mg} / \mathrm{l})$ & $7.17 \pm 2.61$ & $92.57 \pm 24.406$ & 6.736 & 0.000 \\
\hline
\end{tabular}

$p<0.05$ : significant, $P>0.05$ : non-significant

Table (2): ANOVA one-way statistical analysis of the studied parameters between the control group and the acute burned group in $1^{\text {st }}, 5^{\text {th, }}$ and $14^{\text {th }}$ day samples:

\begin{tabular}{|c|c|c|c|c|c|c|}
\hline & \multirow{2}{*}{$\begin{array}{c}\text { Control group } \\
\text { No. (10) }\end{array}$} & \multicolumn{2}{|c|}{ Accute burned group No. (30) } & \multirow{2}{*}{} \\
\hline & Mean \pm SD & Day 1 & Day 5 & Day 14 & \multirow{2}{*}{ Fc } & \multirow{2}{*}{ P } \\
\cline { 3 - 6 } & & Mean \pm SD & Mean \pm SD & Mean \pm SD & & \\
\hline $\begin{array}{c}\text { Plasma } \\
\text { cholinesterase(u/l) }\end{array}$ & $7692.00 \pm 1426.36$ & $3985.63 \pm 1263.07$ & $3197.7 \pm 1030.861$ & $3420.17 \pm 1283.854$ & 126.35 & $<0.0001$ \\
\cline { 1 - 6 } Platelets (10//ul) & $346.83 \pm 103.3$ & $315.47 \pm 64.49$ & $216.5 \pm 83.82$ & $351.50 \pm 39.17$ & 63.18 & $<0.0001$ \\
\hline Albumin (g/dl) & $4.18 \pm 0.64$ & $3.4 \pm 0.77$ & $2.57 \pm 0.78$ & $2.67 \pm 0.78$ & 21.05 & $<0.0001$ \\
\hline CRP (mg/l) & $7.17 \pm 2.61$ & $92.75 \pm 24.4$ & $125.4 \pm 48.96$ & $106.8 \pm 52.94$ & 24.15 & $<0.0001$ \\
\hline
\end{tabular}

$p<0.05$ : significant, $P>0.05$ : non significant 
Table (3): Spearman correlation coefficients test between studied parameters levels and the total burn surface area (TBSA)

\begin{tabular}{|c|c|c|}
\hline \multirow[t]{2}{*}{ Variables } & \multicolumn{2}{|c|}{ TBSA } \\
\hline & $\mathbf{r}$ & $\mathbf{P}$ \\
\hline \multicolumn{3}{|l|}{ Plasma cholinesterase } \\
\hline $\begin{array}{c}\text { Day } 1 \\
\text { Day } 7 \\
\text { Day } 14\end{array}$ & $\begin{array}{l}-0.821^{* *} \\
-0.767^{* *} \\
-0.861^{* *}\end{array}$ & $\begin{array}{l}<0.0001 \\
<0.0001 \\
<0.0001\end{array}$ \\
\hline \multicolumn{3}{|l|}{ Platelets } \\
\hline $\begin{array}{c}\text { Day } 1 \\
\text { Day } 7 \\
\text { Day } 14\end{array}$ & $\begin{array}{l}-0.507^{* *} \\
-0.736^{* *} \\
-0.646^{* *}\end{array}$ & $\begin{array}{c}0.004 \\
<0.0001 \\
<0.0001 \\
\end{array}$ \\
\hline \multicolumn{3}{|l|}{ Albumin } \\
\hline $\begin{array}{c}\text { Day } 1 \\
\text { Day } 7 \\
\text { Day } 14\end{array}$ & $\begin{array}{c}-0.363^{*} \\
-0.557^{* *} \\
-0.664^{* *}\end{array}$ & $\begin{array}{c}0.049 \\
0.001 \\
<0.0001 \\
\end{array}$ \\
\hline \multicolumn{3}{|l|}{ CRP } \\
\hline $\begin{array}{c}\text { Day } 1 \\
\text { Day } 7 \\
\text { Day } 14\end{array}$ & $\begin{array}{c}0.337 \\
0.884^{* *} \\
0.812^{* *}\end{array}$ & $\begin{array}{c}0.069 \\
<0.0001 \\
<0.0001\end{array}$ \\
\hline
\end{tabular}

*. Correlation is significant at the 0.05 level (2-tailed), **. Correlation is significant at the 0.01 level (2-tailed).

Table (4): Independent test, comparison between survivors and non survivors as regards studied parameters at different studied periods.

\begin{tabular}{|c|c|c|c|c|}
\hline & Survivors subgroup & Non -survivors subgroup & \multirow{2}{*}{$\mathbf{T}$} & \multirow{2}{*}{$\mathbf{P}$} \\
\hline & No. $=21$ & No. $=9$ & & \\
\hline Plasma cholinesterase (u/l) & Mean \pm SD & Mean \pm SD & & \\
\hline $\begin{array}{l}\text { Day } 1 \\
\text { Day } 5 \\
\text { Day } 14\end{array}$ & $\begin{array}{l}4631.10 \pm 898.39 \\
3698.71 \pm 794.82 \\
4110.38 \pm 830.72\end{array}$ & $\begin{array}{l}2479.56 \pm 346.34 \\
2028.67 \pm 276.53 \\
1809.67 \pm 285.16\end{array}$ & $\begin{array}{l}9.457 \\
8.503 \\
11.24\end{array}$ & $\begin{array}{l}<0.0001 \\
<0.0001 \\
<0.0001\end{array}$ \\
\hline \multicolumn{5}{|l|}{ Platelets $\left(10^{3} / \mathrm{ul}\right)$} \\
\hline $\begin{array}{c}\text { Day } 1 \\
\text { Day } 5 \\
\text { Day } 14\end{array}$ & $\begin{array}{l}332.95 \pm 52.05 \\
254.90 \pm 67.83 \\
391.19 \pm 68.87\end{array}$ & $\begin{array}{l}274.67 \pm 75.02 \\
126.89 \pm 32.57 \\
243.33 \pm 98.03\end{array}$ & $\begin{array}{l}2.46 \\
5.36 \\
4.74\end{array}$ & $\begin{array}{c}0.02 \\
<0.0001 \\
<0.0001\end{array}$ \\
\hline \multicolumn{5}{|l|}{ Albumin (g/dl) } \\
\hline $\begin{array}{c}\text { Day } 1 \\
\text { Day } 5 \\
\text { Day } 14\end{array}$ & $\begin{array}{l}3.57 \pm 0.75 \\
2.89 \pm 0.69 \\
3.05 \pm 0.62\end{array}$ & $\begin{array}{l}2.89 \pm 0.65 \\
1.82 \pm 0.35 \\
1.81 \pm 0.23\end{array}$ & $\begin{array}{l}2.37 \\
5.36 \\
4.74\end{array}$ & $\begin{aligned} & 0.025 \\
< & 0.0001 \\
< & 0.0001\end{aligned}$ \\
\hline \multicolumn{5}{|l|}{ CRP (mg/l) } \\
\hline $\begin{array}{c}\text { Day } 1 \\
\text { Day } 5 \\
\text { Day } 14\end{array}$ & $\begin{array}{l}88.86 \pm 16.60 \\
96.52 \pm 16.01 \\
77.00 \pm 15.59\end{array}$ & $\begin{array}{c}101.22 \pm 36.75 \\
192.78 \pm 27.49 \\
176.44 \pm 42\end{array}$ & $\begin{array}{c}-1.29 \\
-12.097 \\
-6.901\end{array}$ & $\begin{aligned} & 0.209 \\
< & 0.0001 \\
< & 0.0001\end{aligned}$ \\
\hline
\end{tabular}


Table (5): Spearman correlation coefficient test between the studied parameters and TBSA in survivors and non survivors burned patients.

\begin{tabular}{|c|c|c|c|c|}
\hline \multirow{2}{*}{} & \multicolumn{4}{|c|}{ TBSA } \\
\cline { 2 - 5 } & \multicolumn{2}{|c|}{ Survivor subgroup (No=21) } & \multicolumn{1}{c|}{ Non-Survivor subgroup (No=9) } \\
\cline { 2 - 5 } & $\mathbf{R}$ & $\mathbf{P}$ & $\mathbf{R}$ & $\mathbf{P}$ \\
\hline Plasma cholinesterase & & & & \\
Day 1 & $-0.445^{*}$ & 0.043 & 0.141 & 0.717 \\
Day 5 & -0.344 & 0.126 & 0.321 & 0.400 \\
Day 14 & $-0.490^{*}$ & 0.024 & 0.148 & 0.703 \\
\hline Platelets & & & & \\
Day 1 & -0.223 & 0.332 & -0.663 & 0.052 \\
Day 5 & -0.354 & 0.115 & 0.118 & 0.762 \\
Day 14 & -0.097 & 0.674 & -0.096 & 0.807 \\
\hline Albumin & & & & \\
Day 1 & 0.103 & 0.657 & -0.131 & 0.736 \\
Day 5 & 0.072 & 0.755 & 0.465 & 0.207 \\
Day 14 & 0.096 & 0.679 & 0.045 & 0.909 \\
\hline CRP & & & & \\
Day 1 & $0.464^{*}$ & 0.034 & 0.241 & 0.533 \\
Day 5 & $0.490^{*}$ & 0.024 & -0.245 & 0.525 \\
Day 14 & $0.515^{*}$ & 0.017 & -0.646 & 0.060 \\
\hline
\end{tabular}

* Correlation is significant at the 0.05 level (2-tailed).

Table (6): Cut off points, AUC, sensitivity and specificity for plasma cholinesterase, albumin and CRP in acute burned group in day 1 sample.

\begin{tabular}{|l|c|c|c|c|c|c|}
\hline & $\begin{array}{c}\text { Cut -off } \\
\text { point }\end{array}$ & $\begin{array}{c}\text { Area } \\
\text { under } \\
\text { curve }\end{array}$ & $\begin{array}{c}\text { Sensitivity } \\
\%\end{array}$ & $\begin{array}{c}\text { Specificity } \\
\%\end{array}$ & $\begin{array}{c}\text { Positive } \\
\text { predictive } \\
\text { value }\end{array}$ & $\begin{array}{c}\text { Negative } \\
\text { predictive } \\
\text { value }\end{array}$ \\
\hline Plasma cholinesterase (u/l) & $\leq 6223$ & 0.963 & 100.00 & 90.00 & 96.8 & 100.0 \\
\hline Albumin (g/dl) & $\leq 3.4$ & 0.782 & 53.33 & 90.00 & 89.5 & 38.1 \\
\hline CRP (mg/l) & $>13$ & 1.000 & 100.00 & 100.00 & 100.0 & 100.0 \\
\hline
\end{tabular}

Table (7): Cut off points, AUC, sensitivity, and specificity for plasma cholinesterase in acute burned group in the different study periods

\begin{tabular}{|l|c|c|c|c|c|c|}
\hline Plasma cholinesterase & $\begin{array}{c}\text { Cut- off } \\
\text { point }\end{array}$ & $\begin{array}{c}\text { Area under } \\
\text { curve }\end{array}$ & Sensitivity\% & Specificity\% & $\begin{array}{c}\text { Positive } \\
\text { predictive } \\
\text { value }\end{array}$ & $\begin{array}{c}\text { Negative } \\
\text { predictive } \\
\text { value }\end{array}$ \\
\hline Day 1 & $\leq 3320$ & 1.000 & 100 & 100 & 100 & 100 \\
\hline Day 5 & $\leq 2568$ & 0.989 & 100.00 & 90.48 & 81.8 & 100.0 \\
\hline Day 14 & $\leq 2214$ & 1.000 & 100 & 100 & 100 & 100 \\
\hline
\end{tabular}

Table (8): Cut off points, AUC, sensitivity, and specificity for platelets in acute burned group in the different study periods.

\begin{tabular}{|l|c|c|c|c|c|c|}
\hline \multicolumn{1}{|c|}{ Platelets } & $\begin{array}{c}\text { Cut- off } \\
\text { point }\end{array}$ & $\begin{array}{c}\text { Area under } \\
\text { curve }\end{array}$ & Sensitivity\% & Specificity\% & $\begin{array}{c}\text { Positive } \\
\text { predictive } \\
\text { value }\end{array}$ & $\begin{array}{c}\text { Negative } \\
\text { predictive } \\
\text { value }\end{array}$ \\
\hline Day 1 & $\leq 310$ & 0.720 & 77.78 & 66.67 & 50.0 & 87.5 \\
\hline Day 5 & $\leq 149$ & 0.984 & 88.89 & 100.00 & 100.0 & 95.5 \\
\hline Day 14 & $\leq 350$ & 0.902 & 88.89 & 80.95 & 66.7 & 94.4 \\
\hline
\end{tabular}


Table (9): Cut off points, AUC, sensitivity and specificity for albumin in acute burned group in the different study periods.

\begin{tabular}{|l|c|c|c|c|c|c|}
\hline \multicolumn{1}{|c|}{ Albumin } & $\begin{array}{c}\text { Cut- off } \\
\text { point }\end{array}$ & $\begin{array}{c}\text { Area } \\
\text { under } \\
\text { curve }\end{array}$ & Sensitivity\% & Specificity\% & $\begin{array}{c}\text { Positive } \\
\text { predictive } \\
\text { value }\end{array}$ & $\begin{array}{c}\text { Negative } \\
\text { predictive } \\
\text { value }\end{array}$ \\
\hline Day 1 & $\leq 3.3$ & 0.765 & 88.89 & 66.67 & 53.3 & 93.3 \\
\hline Day 5 & $\leq 2.3$ & 0.913 & 100 & 80.95 & 69.2 & 100.0 \\
\hline Day 14 & $\leq 2.2$ & 0.894 & 100 & 90.48 & 81.8 & 100.0 \\
\hline
\end{tabular}

Table (10): Cut off points, AUC, sensitivity and specificity for CRP in acute burned group in the different study periods.

\begin{tabular}{|l|c|c|c|c|c|c|}
\hline \multicolumn{1}{|c|}{ CRP } & $\begin{array}{c}\text { Cut- off } \\
\text { point }\end{array}$ & $\begin{array}{c}\text { Area } \\
\text { under } \\
\text { curve }\end{array}$ & Sensitivity\% & Specificity\% & $\begin{array}{c}\text { Positive } \\
\text { predictive } \\
\text { value }\end{array}$ & $\begin{array}{c}\text { Negative } \\
\text { predictive } \\
\text { value }\end{array}$ \\
\hline Day 5 & $>126$ & 1.000 & $100.0 \%$ & $100.0 \%$ & $100.0 \%$ & 100.0 \\
\hline Day 14 & $>106$ & 1.000 & $100.0 \%$ & $100.0 \%$ & $100.0 \%$ & 100.0 \\
\hline
\end{tabular}

Table (11): Plasma cholinesterase sensitivity with the different studied parameters in acute burned group:

\begin{tabular}{|l|c|c|c|}
\hline \multicolumn{3}{|c|}{ Plasma cholinesterase } & Day 14 \\
\hline \multicolumn{1}{|c|}{ Index } & Day 1 & Day 5 & $100 \%$ \\
\hline CRP & $50 \%$ & $100 \%$ & $100 \%$ \\
\hline Albumin (AL) & $94.5 \%$ & $100 \%$ & $94.5 \%$ \\
\hline Platelets (PL) & $98 \%$ & $94.5 \%$ & $96.3 \%$ \\
\hline CRP/PL & $59.5 \%$ & $96.3 \%$ & $100 \%$ \\
\hline PL/AL & $63 \%$ & $100 \%$ & $96.3 \%$ \\
\hline CRP/PL/AL & $89 \%$ & $96.3 \%$ & $97.3 \%$ \\
\hline
\end{tabular}

\section{Discussion}

\section{Plasma cholinesterase:}

In the present study, plasma cholinesterase level was measured in day 1, 5 and 14 after burn.The study showed that plasma cholinesterase level was reduced in the acute burned group. There was a statistical significant difference between the acute burned cases and the control as regard plasma cholinesterase, this finding is consistent with the results reported by Zhao et al. (2018) on changes in plasma cholinesterase after burn injuries, their results showed that the plasma cholinesterase activity was lower in the patient groups than in the control group at all the time points observed.

There are some proposed possible mechanisms for decreasing plasma cholinesterase activity in burns patients, including: (1) reduced hepatic synthesis of plasma cholinesterase due to impaired liver function; (2) hemodilution resulting from a large amount of fluid infusion during early resuscitation; (3) increased consumption of enzymes due to high catabolism induced by stress; (4) capillary leak syndrome, caused by shock, leading to increased extravascular transport of plasma cholinesterase (Woodson et al., 2018).

There was significant reduction in day 5 when compared with day 1 and there is improvement in day
14 when compared with day 5, the plasma cholinesterase activity reached the lowest level after injury in day 5, this finding was consistent with the data reported by Zhang et al. (2018) which showed that after burn, the activity of plasma cholinesterase decreased significantly, and there was a tendency to decrease firstly and increase afterwards.

This finding was also consistent with the data reported by Obeso et al. (2017) that showed that the magnitude as well as the rate of fall of plasma cholinesterase activity was found to be closely correlated with the severity of burn injury. Minimum levels were often reached 5 to 6 days after the burn injury, at which time the activity might have been depressed by more than $80 \%$. In the most severely burned patients, the activity sometimes remained low for months despite wound healing. Apart from the severity of the burn injury in the individual patient, several important factors determined the level of serum cholinesterase activity at a given time. These included the presence or absence of local or systemic infections, the event of recent surgery such as slough removal or skin grafting, and blood transfusions.

The correlation between the total burn surface area and the plasma cholinesterase level was analyzed at each time point, there was negative correlation 
between plasma cholinesterase concentration and the total burn surface area, the greater the total burn surface area is, the more drop in the level of the plasma cholinesterase, and it is a logic result, the greater the total burn surface area is, the more impairment in the liver function.

This finding was consistent with the data reported by Zhang et al. (2018) which showed that the plasma cholinesterase activity was higher in 30\%49\%TBSA group than in the 50\%-79\% TBSA group and in $80 \%$ TBSA group, and the activity was higher in 50\%$79 \%$ TBSA group than in $80 \%$ TBSA group $(\mathrm{P}<0.05)$.

In addition, according to the prognosis, the patients were divided into the survivors' group and the non-survivor group.

The plasma cholinesterase level at each time point and the range of plasma cholinesterase level decrease at the different study periods were compared between the two groups : survived group and nonsurvived group and there was a statistical significant reduction in the level of the plasma cholinesterase in non survivors when compared with survivors, this finding was consistent with the data reported by Cheng et al. (2018) that showed that the plasma cholinesterase activity was significantly higher in the survivors than in the non survivors and the magnitude of decrease in plasma cholinesterase level was less significant in the survival group, after the burn plasma cholinesterase activity decreased continuously for 7 days after injury in both the survivor and non-survivor subgroups, but was significantly lower in the non-survival subgroup in days 1, 5, and 14 samples after burn.

The present study showed that there was negative correlation between plasma cholinesterase and TBSA in day 1 and 14 in survivors subgroup.

Non-specific inflammation occurs after severe burn. During this process, plasma proteins synthesized in the liver are defined as Acute Phase Proteins when their concentrations increase or decrease by at least $25 \%$. Some APPs, such as CRP, increase in concentration and are known as positive APPs. Conversely, other APPs, such as albumin decrease in concentration and are known as negative APPs (Iliev and Georgieva, 2018).

Plasma cholinesterase level decreased after burn and is considered as negative acute phase protein and participates in regulation of the inflammatory response.

The mechanism for the involvement of plasma cholinesterase in the inflammatory response may be related to the activation of the 'cholinergic antiinflammatory pathway' (Cerejeira et al., 2012). Acetylcholine can bind to different receptors and play different physiological roles (Kini, 2019). After binding to the $\alpha 7$ nicotinic acetylcholine receptor, acetylcholine can inhibit the inflammatory mediators (i.e., the so-called 'cholinergic anti-inflammatory pathway') and have an anti-inflammatory effect via activation of the cholinergic system (Kanashiro et al., 2017).

Plasma cholinesterase is an important part of the cholinergic system since it is a hydrolase that is upstream of the neurotransmitter cholinesterase inhibitors also had anti-inflammatory effects (Lazarevic-Pasti et al., 2017).
Therefore, acetylcholinesterase activity decreases during the inflammatory response after trauma, in turn increasing the utilization of acetylcholine, thereby regulating inflammation (Faiq et al., 2019).

In the present study plasma cholinesterase was found to be significantly and positively correlated with albumin, at all-time points and significantly and negatively correlated with CRP at all time points except post-injury day 1 . Thus, it appears that changes in plasma cholinesterase activity are consistent with negative Acute Phase Proteins concentrations and the correlations between them are significant. Furthermore, since proteins are synthesized in the liver and plasma cholinesterase activity was reduced by more than $25 \%$ in day 1,5 , and 14 , compared with the control, plasma cholinesterase fits the definition of an APP and can be regarded as a negative APP.

The present study data were consistent with the results reported by Ba et al. (2014) which showed that plasma cholinesterase activity decreases significantly after injury in patients with severe trauma. A greater decrease appears to indicate a more severe injury and a poorer prognosis.

Plasma cholinesterase activity assay is a valid biological marker of malnutrition, inflammation, and liver synthetic ability with a relatively low cost and high clinical informative power. Plasma cholinesterase determination is a routine clinical laboratory test, scheduled in all laboratory panels at hospital admission as well as for outpatient evaluation; on demand, it is also possible to add this test in the urgent exams' panels. Its cost is similar to that of other routine exams (serum glucose, urea, creatinine dosage, etc.), including the assay of albumin, prealbumin, transferrin, and lymphocyte count. Plasma cholinesterase may therefore enter in a cluster of selected prognostic parameters, useful to complete the clinical judgment (Santarpia et al., 2013).

Plasma cholinesterase assessment should be included in routine clinical diagnostic procedures to evaluate patient clinical conditions, in particular in cases of inflammation and/or protein-energy malnutrition. This parameter has a prognostic value varying from disease to disease; for example, it indicates inadequate availability of substrates for liver synthesis and positively correlates with the effectiveness of nutritional support in case of malnutrition; plasma cholinesterase has a survival predictive role in cancer patients and seems to correlate with disease progression. Finally, reduced levels of plasma cholinesterase suggested negative outcomes (death or worsening of clinical conditions) in patients on artificial nutrition (Santarpia et al., 2019).

Serum albumin:

Albumin level was analyzed in the present study, and results showed that when its level was compared between the acute burned group and the control in day 1 , there was a significant reduction in the acute burned group.

This finding was consistent with the data reported by Saleh et al. (2018) that showed that there was a significant difference between the level of the serum albumin between controls and burned cases on day 1 samples. 
Burns induce a strong inflammatory response that causes the release of the vasoactive substances, which increases the skin permeability to water, albumin, and even larger protein molecules, this process peaks during the first 24 hours, coupled with a reduction in the albumin mRNA response to the burn and an increased synthesis and accumulation of acute-phase reactants. After this initial phase, hypoalbuminemia persists because of the lack of its synthesis, its loss through damaged skin areas, and deficiencies in nutritional support (Aguayo-Becerra et al., 2013).

The present study showed significant reduction in the albumin level in day 5 and 14 when compared with day 1 and there was negative correlation between the albumin level and the total burn surface area in day 1, 5 and 14 samples, the greater the total burn surface area was the more drop in the albumin level, hypoalbuminemia was closely related to the burned area, which is considered to have predictive value for mortality.

This finding was consistent with the data reported by Aguayo-Becerra et al. (2013) who found a severe hypoalbuminemia $(<2 \mathrm{~g} / \mathrm{dL})$, which was observed in 15 of the 73 burn patients and it was strongly associated with an increase in the affected area $(p<0.001)$.

Burns produce hypermetabolic and hypercatabolic responses, which are related to the extent and depth of the injuries. Burns affecting $>20 \%$ of the body surface cause a major loss of extracellular fluids, thereby inducing shock by increasing vascular permeability and reducing plasma albumin from the wound exudations (Saleh et al., 2018).

There was a statistical significant reduction in the level of the albumin in non survivors when compared with survivors; the albumin level was much less in non survivors than survivors in this current study.

This finding was consistent with the data reported by Aguayo-Becerra et al. (2013), that showed that patients with albumin levels $<2 \mathrm{~g} / \mathrm{dL}$ had a mortality risk of $>80 \%$, with $84 \%$ sensitivity and $83 \%$ specificity. In admission, the albumin level could be used as a sensitive and specific marker of burn severity and as an indicator of mortality.

The results of the current study were in consistent with the data reported in a cross-sectional study with fewer patients, Mansour et al., (2017) reported a mortality rate of $<10 \%$ in severely burn patients in whom hypoalbuminemia was frequently observed, demonstrating a significant association between the extent of the burn and the serum albumin level, which is consistent with the present study. However, the authors found no relationship between the level of this protein and hospital stay, complication rate, or mortality which is inconsistent with the present study.

The results in the present study were consistent with the data reported by Aguayo-Becerra et al. (2013) who conducted a cross-sectional analysis of 147 burn patients and its results showed that albumin level not only predicted mortality but also the risk of developing kidney failure, which eventually resulted in
$100 \%$ mortality in the 28 patients who developed this complication.

The results reported by the present study were consistent with the data reported by Eljaiek and Dubois (2013) who performed a cross-sectional study of 56 burned patients with a total burn size of 30.3 $\pm 10.9 \%$ : $\quad 36 \quad(64.3 \%) \quad$ patients had hypoalbuminemia $(<30 \mathrm{~g} / \mathrm{L})$ and 20 (35.7\%) had albumin levels $>30 \mathrm{~g} / \mathrm{L}$. The authors demonstrated that the presence of hypoalbuminemia in the first 24 hours after injury was an independent predictor of organ dysfunction. They observed no mortality in the patients with normal albumin levels but $16.7 \%$ mortality in patients with hypoalbuminemia. However, the difference was not statistically significant, likely because the sample size was small.

The albumin is the only modifiable factor related to outcomes because its level can be corrected by administering human albumin solutions.

Platelets:

In the present study platelets showed that there was no statistically significant difference between the acute burned group and control in day 1, there was significant reduction in the level of day 5 when compared with day 1 and day 14, this finding was consistent with the data reported by Warner et al. (2011) that indicated that thrombocytopenia is initially seen in patients with burn injury as a transient occurrence during the first week after injury. Subsequent decreases occur later in the course of treatment and are commonly due to sepsis, dilutional effects, and medication exposure.

Platelets count decreases due to bacterial infection associated with bacteremia which leads to platelets consumption, Thrombocytopenia usually occurs early and can be an early indication of bacteremia in burn patients (Yeaman, 2019).

There was negative correlation between the platelets count and the total burn surface area, this currently finding was consistent with the data reported by Marck et al. (2013) that indicated that there was a nadir in day 3 followed by a peak in day 15 and a temporary thrombocytosis. Age and TBSA\% influence this course. In the pgresent study only TBSA \% influenced the course and that it was because the ages included in the study were from 18-45 the extremes of age were not included.

In the present study there was statistical significant reduction in the level of the platelets in non survivors when compared with survivors. The incidence of thrombocytopenia in survivors and non survivors was statistically significant. Non survivors demonstrated a more profound drop in platelet count during the first week after injury and had a more depressed platelet recovery curve than survivors, this finding was consistent with the data reported by Marck et al. (2013) that showed that survivors showed decrease in platelet count in the initial post-burn days followed by rise in platelet count to the normal level on subsequent post-burn days of 32 burn patients, 14 survived having rebound increase in platelet count of 30 patients in survivors, platelet count on the $7^{\text {th }}$ post- 
burn day decreased below the normal level. Seventh day onward, it started increasing and reached up to the normal levels on the 15th post-burn day Thus, the rising trend in platelet count in survivors after initial fall coincides with this study.

Declining in platelet count was observed with development and progression of septicemia. Thus, this declining platelet count can be correlated with bad prognosis of patients. The platelets were observed for progressive decrease in their count on subsequent postburn days in non-survivors. They correlated this observation with bad prognosis of the patient (Marck et al., 2013)

The early development of thrombocytopenia with depressed in the burn patient is associated with increased mortality risk and is influenced by the extent of burn, inhalation injury and the development of sepsis (Aguayo-Becerra et al., 2013).

However Marck et al. (2013) recorded that platelet count on any post-burn day is not primarily dependent on the extent of the burn injury but depends only on sepsis in burns.

$C$-Reactive protein:

In the present study as regards CRP there was a statistical significant difference between acute burned cases and the control, there was significant increase in the level of CRP at different study periods when compared with controls, significant increase in day 5,14 when compared with day 1, this finding was consistent with the results reported by Lavrentieva et al. (2007) that showed that CRP was elevated in all burned patients but didn't differ significantly between systemic inflammatory response syndrome noninfected and septic patients.

CRP is considered as a general marker for the inflammatory response, is an acute phase protein synthesized and released by the liver. CRP is dramatically increased post burn, but decreases over the hospital course (McPherson et al., 2011).

CRP an acute phase serum protein, is a surrogate for the pro-inflammatory interleukin IL-6 (Khan et al., 2017).

It activates the complement system and binds to Fc receptors. Significant rise in CRP indicates clinically relevant inflammation, and in contrast, the absence of a high CRP helps in exclusion of infection/inflammation (Esenwa and Elkind, 2016). For example, CRP plasma concentrations exceeding $8 \mathrm{mg} / \mathrm{dl}$ can distinguish the inflammatory response due to infection from other types of inflammation indicating that CRP levels can be predictive of infection (Sproston and Ashworth, 2018). John et al. (2017) showed that a rise in CRP serum levels significantly predicted the incidence of major infection 2.3 days before sepsis occurred.

There was positive correlation between CRP and total burn surface area in day 5, 14 as there was no correlation in day 1 , there was no statistical significant difference in the level of the CRP in non survivors when compared with survivors in day one, but there was statistical significant increase in the level of the CRP in non survivors when compared with living persons in day 5 and 14, this finding was consistent with the data reported by Huang et al. (2018) which showed that CRP values significantly correlated with burn size, survival and gender. Significantly higher levels of CRP were found in large burns, in nonsurvivors, and in females, $\mathrm{p}<0.05$.

In the present study, we did find a significant difference in the CRP levels over time between survivors and non-survivors groups starting in days post burn Survivors had lower CRP levels at every time point except day sample.

In a follow-up study evaluated CRP and pro calcitonin (PCT), was found that PCT did not correlate and predict sepsis; however, a rise in CRP of $1.5 \mathrm{mg} / \mathrm{dl}$ indicated sepsis and a rise of $3 \mathrm{mg} / \mathrm{dl}$ indicated severe bacterial or fungal infection (Jeschke et al., 2013).

A study by Lavrentieva et al. (2007) showed that CRP did not correlate with sepsis incidence. Controversy exists regarding conflicting results from studies that investigated the effect of CRP as the marker of severe infections after burn.

The data in the present study were consistent with the data reported by Jeschke et al. (2013) that implied that CRP is not a predictor of infection, however, is a good marker that reflects the homeostasis of the burned patient.

Predicting prognosis based on plasma cholinesterase activity in severe burn patients:

ROC curves for predicting prognosis were plotted and they showed that the best cut off point for plasma cholinesterase in day 1 for differentiation between the burned cases and the control was found $\leq$ $6223(\mathrm{u} / \mathrm{l})$ with sensitivity of $100 \%$, specificity of $90 \%$ and area under curve (AUC) of $96.3 \%$ while for albumin the best cut off point was found $\leq 3.4(\mathrm{~g} / \mathrm{dl})$ with sensitivity of $53.33 \%$, specificity of $90 \%$ and AUC of 78.2 while CRP cut off point between cases and controls was found $>13$ (mg/l) with sensitivity of $100 \%$, specificity of $100 \%$ and AUC of $100 \%$.

Another ROC curve for plasma cholinesterase as a prognostic marker showed that the best cut off point for plasma cholinesterase as a prognostic marker in day 1 was found $\leq 3320$ with sensitivity of $100 \%$, specificity of $100 \%$, in day 5 the best cut off point was found $\leq 2568$ with sensitivity of $100 \%$, specificity of $90.48 \%$, and in day 14 the best cut off point was found $\leq 2214$ with sensitivity of $100 \%$ and specificity of $100 \%$.

A ROC curve for the albumin as a prognostic marker showed that the best cut off point for albumin as a prognostic marker in day 1 was found $\leq 3.3$ with sensitivity of $88.89 \%$, specificity of $66.67 \%$, in day 5 the best cut off point was found $\leq 2.3$ with sensitivity of $100 \%$, specificity of $80.95 \%$, and in day 14 the best cut off point was found $\leq 2.2$ with sensitivity of $100 \%$ and specificity of $90.48 \%$.

A ROC curve for the platelets as a prognostic marker showed that the best cut off point for platelets as a prognostic marker in day 1 was found $\leq 310$ with sensitivity of $77.78 \%$, specificity of $66.67 \%$, in day 5 the best cut off point was found $\leq 149$ with sensitivity of $88.89 \%$, specificity of $100 \%$, and in day 14 the best cut off point was found $\leq 350$ with sensitivity of $88.89 \%$ and specificity of 80.95 . 
A ROC curve for CRP as a prognostic marker showed that the best cut off point for CRP in day 7 was found $>126$ with sensitivity of $100 \%$, specificity of $100 \%$, and in day 14 the best cut off point was found $>106$ with sensitivity of $100 \%$ and specificity of $100 \%$. The sensitivity of plasma cholinesterase with the other parameters:

In day 1 the plasma cholinesterase sensitivity was the highest when it was measured alone (100\%), it was the lowest when combined with CRP (50\%).

In day 5 the plasma cholinesterase sensitivity was the highest (100\%) when it was measured alone, combined with CRP, when combined with albumin and when combined with CRP, albumin collectively, it was the lowest when combined with platelets (94.5\%).

In day 14 the plasma cholinesterase sensitivity was the highest $(100 \%)$ when it was measured alone, combined with CRP, when combined with albumin and when combined with CRP, albumin collectively, it was the lowest when combined with platelets (94.5\%).

The high sensitivity of plasma cholinesterase with albumin and CRP in comparison with its sensitivity with platelets is due to the non-specific inflammation that occurs after severe burn. During this process, plasma proteins synthesized in the liver which are called acute phase proteins (APPs) when their concentrations increase or decrease by at least $25 \%$. Some APPs, such as CRP increase in concentration and are known as positive APPs. Conversely, other APPs, such as albumin decrease in concentration and are known as negative APPs. In the current study, CRP increased continuously, while albumin decreased after injury, similar to plasma cholinesterase activity, Moreover, plasma cholinesterase was found to be significantly and positively correlated with albumin at all-time points and significantly and negatively correlated with CRP at all-time points except post-injury day 1 . Thus, it appears that changes in plasma cholinesterase activity are consistent with negative APPs concentrations and the correlations between them are significant. Furthermore, since proteins are synthesized in the liver and plasma cholinesterase activity was reduced by more than $25 \%$ in days 1,5 , and 14 samples compared with the control, plasma cholinesterase fits the definition of an APP and can be regarded as a negative APPs (Ansar and Ghosh, 2016).

From medicolegal point of view we can decide if the death was due to physician negligence or as an anticipated consequence of burn injury by measuring the previous investigating predictors of mortality with high sensitivity in cases of burn injuries that can be determined in early stage of burn before start of medical interventions to reflect severity of injury and body response to it.

\section{Conclusion}

The current study concluded that plasma cholinesterase can be measured as a prognostic index alone with $100 \%$ sensitivity in day 1, 5 and 14 post burn. When it is measured adjuvant to platelets in day 1 sensitivity is $98 \%$, to CRP in day 5 and 14 , the sensitivity is $100 \%$, to albumin in day 5,14 , and the sensitivity is $100 \%$. When the three parameters (plasma cholinesterase, albumin and CRP) were collectively measured the sensitivity is $100 \%$.

\section{Recommendations}

The present study recommended Plasma cholinesterase to be measured as a routine clinical laboratory test for the admitted acutely burned patient.

- Plasma cholinesterase to be measured alone as a prognostic index or adjuvant to albumin, CRP or both is advised.

- Since plasma cholinesterase is synthesized in liver, its measuring is unsuitable for patients with major liver dysfunction so further similar studies are advised to be conducted on severe burnt hepatic patients.

- Since plasma cholinesterase is present in readily available blood products caution should be considered when interpreting its level in burned patients received blood transfusions.

- Further study to be conducted on a larger sample size.

\section{References}

Aguayo-Becerra OA, Torres-Garibay C, Macías-Amezcua MD, et al., (2013): Serum albumin level as a risk factor for mortality in burn patients. Clinics. 68(7):940-5.

Aktas N, Gulacti U, Lok U, et al., (2018): Characteristics of the traumatic forensic cases admitted to emergency department and errors in the forensic report writing. Bulletin of Emergency \& Trauma. 6(1):64.

Ansar W and Ghosh S (2016): Acute-Phase Proteins and Responses and Their Application in Clinical Chemistry. In: Biology of C Reactive Protein in Health and Disease. Springer; p. 45-65.

Ba L, Wu D, Qian A, Zhang M, Xiong B. Dynamic changes of serum cholinesterase activity after severe trauma. J Zhejiang Univ Sci B. 2014; 15(12):102331.

Cerejeira J, Nogueira V, Luís P, et al., (2012): The cholinergic system and inflammation: common pathways in delirium pathophysiology. Journal of the American Geriatrics Society. 60(4):669-75.

Eljaiek R and Dubois M-J (2013): Hypoalbuminemia in the first $24 \mathrm{~h}$ of admission is associated with organ dysfunction in burned patients. Burns. 39(1):113-8.

Esenwa CC and Elkind MS (2016): Inflammatory risk factors, biomarkers, and associated therapy in ischaemic stroke. Nat Rev Neurol. 12(10):594.

Faiq MA, Wollstein G, Schuman JS, et al., (2019): Cholinergic nervous system and glaucoma: From basic science to clinical applications. Progress in retinal and eye research. 72:100767.

Friedstat J, Brown DA and Levi B (2017): Chemical, electrical, and radiation injuries. Clin Plast Surg.;44(3):657.

Huang Q, Huang C, Luo Y, et al., (2018): Circulating lncRNA NEAT1 correlates with increased risk, elevated severity, and unfavorable prognosis in sepsis patients. Am J Emerg Med. 2018; 36(9):1659-63. 
Iliev PT and Georgieva TM (2018): Acute phase proteins in sheep and goats-function, reference ranges and assessment methods: an overview. Bulgarian Journal of Veterinary Medicine. 21(1).

Jeschke MG, Finnerty CC, Kulp GA, et al., (2013): Can we use C-reactive protein levels to predict severe infection or sepsis in severely burned patients? Int J Burns Trauma. 3(3):137.

John J, Chisthi MM, and Kuttanchettiyar KG (2017): Creactive protein: an early predictor of sepsis in patients with thermal burns. Int Surg J. 4(2):628-32.

Kanashiro A, Sônego F, Ferreira RG, et al., (2017): Therapeutic potential and limitations of cholinergic anti-inflammatory pathway in sepsis. Pharmacological research. 117:1-8.

Khan AN, Jacobsen HE, Khan J, et al. (2017): Inflammatory biomarkers of low back pain and disc degeneration: a review. Ann N Y Acad Sci. 1410(1):68-84

Kini RM (2019): Toxins for decoding interface selectivity in nicotinic acetylcholine receptors. Biochemical Journal. 476(10):1515-20.

Lavrentieva A, Kontakiotis T, Lazaridis L, et al., (2007): Inflammatory markers in patients with severe burn injury: what is the best indicator of sepsis? Burns. 2007; 33(2):189-94.

Lazarevic-Pasti T, Leskovac A, Momic T, et al., (2017): Modulators of acetylcholinesterase activity: From Alzheimer's disease to anti-cancer drugs. Current Medicinal Chemistry. 24(30):3283-309.

Mansour OF, Megahed MA, El-Wahsh RA, et al., (2017): Pulmonary complications for predicting mortality among major burn victims. Menoufia Med J. 30(1):234.

Marck RE, Montagne HL, Tuinebreijer WE, et al., (2013): Time course of thrombocytes in burn patients and its predictive value for outcome. Burns. 39(4):71422.

Nakache V, Perez B, and Cantaloube A (2011): Medicolegal assessment in the sequelae of burns ( $2^{\text {nd }}$ part): the lawyer's point of view. InAnnales de Chirurgie Plastique et Esthetique 56(5): 488-492.
Clinical relevance of liver histopathology and different histological classifications of NASH in adults. Expert Rev Gastroenterol Hepatol. 12(4):351-67.

Obeso JA, Stamelou M, Goetz CG, et al. (2017): Past, present, and future of Parkinson's disease: a special essay on the 200th anniversary of the shaking palsy. Mov Disord. 32(9):1264-310.

Saleh SM, Hassan MH, Tohamy AM, et al., (2018): Study of some biochemical changes in burned patients. SVU-International J Med Sci. 2(1).

Santarpia L, Grandone I, Contaldo F, et al., (2013): Butyrylcholinesterase as a prognostic marker: a review of the literature. J Cachexia Sarcopenia Muscle. 4(1):31-9.

Snell JA, Loh NH, Mahambrey T, et al., (2013): Clinical review: the critical care management of the burn patient. Critical Care. 17(5):1-0.

Sproston NR and Ashworth JJ (2018): Role of C-reactive protein at sites of inflammation and infection. Front Immunol. 9:754.

Walczak S and Velanovich V (2018): Improving prognosis and reducing decision regret for pancreatic cancer treatment using artificial neural networks. Decis Support Syst. 106:110-8.

Warner P, Fields AL, Braun LC, et al., (2011): Thrombocytopenia in the pediatric burn patient. $\mathrm{J}$ Burn care Res. 32(3):410-4.

Woodson LC, Sherwood ER, Kinsky MP, et al., (2018): Anesthesia for burned patients. In: Total burn care. Elsevier; p. 131-57.

Yeaman MR (2019): The role of platelets in antimicrobial host defense. In: Platelets. Elsevier; p. 523-46.

Zhang G, Shen C, Cheng W, et al., (2018): The relation between serum cholinesterase level and both the disease progress and prognosis of massively burned patients: a retrospective study. Med J Chinese People's Lib Army. 43(3):224-38.

Zhao Y, Zhang Z, Gao J, et al., (2018): Arabidopsis duodecuple mutant of PYL ABA receptors reveals PYL repression of ABA-independent SnRK2 activity. Cell reports. 23(11):3340-51

Nascimbeni F, Ballestri S, Machado MV, et al., (2018):

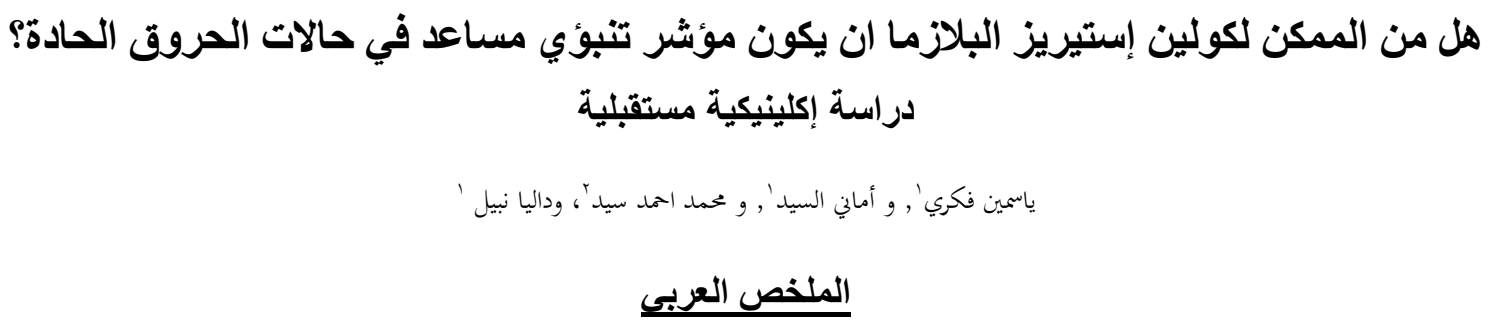

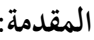

إن أهمية المؤشرات التكهنية في حالات الحروق لاتعتمد فقط علي التتبؤ بحالة المريض ولكن أيضا من أجل نوزيع

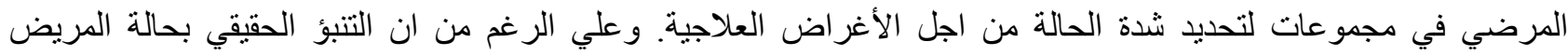

المستقبلية يعد اهم وأول سؤال لدي اسرة المريض,فإن القياس الكمي لحالة المرضى باستخدام تلك المؤشرات يعد ذا أهمية كبيرة

لمر اكزعلاج الحروق في اتخاذ قرار السياسة العلاجية. فكلما كانت دقة هذا المؤشرات عالية, كلما كانت ذو فائدة كبيرة للغرض بـات

المستخدمه من أجله ـ ونظرًا لاحتمال حدوث عدة مضاعفات بعد الإصابة بالحروق (بعضها مميت) فإن ادعاء الإهمال أمر وارد. 
وقد يدعي أقارب المريض أن الوفاة ناتجة عن سوء إدارة الفريق الطبي المعالج وليس نتيجة المضاعفات التي لا مفر من

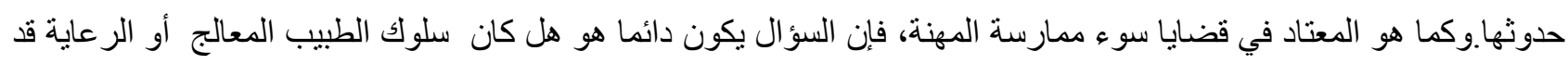
إنحرف عن معيار الرعاية المعدول به أم لا؟.

الهدف من هذه الدراسة هو تقييم الدور المحتمل للبلازما كولين إستيريز كمؤشر تنبؤي مساعد في حالات المرضى الذين

يعانون من حروق شديدة للتأكد من إدعاءات سوء الممارسة.

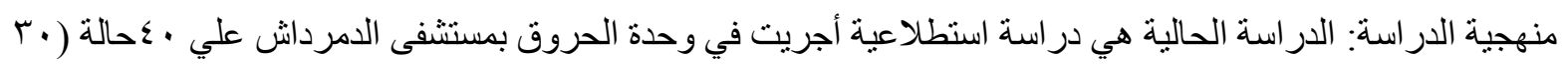
مريض حروق حادة و • ا مجموعة ضابطة). تم جمع عينات الدم من كل حالة تحت الدراسة في اليوم الأول والخامس و الرابع عشر بعد حدوث الحرق لقياس مستوي كولين إستيريز البلازما, الالبومين, الصفائح الدموية وبروتين سي التفاعلي. كان هناك

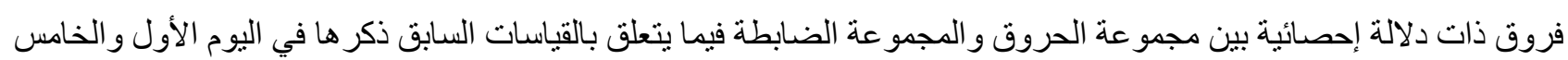
و الر ابع عشر باستثناء تركيز الصفائح الدموية في عينة اليوم الأول. كان هناك ارتباط سلبي ذو دلالة إحصائية بين كولينستريز البلازما ,الصفائح الدموية ,الألبومين و إجمالي مساحة سطح الحرق بينما وجد ارتباط إيجابي مع بروتين سي التفاعلي ـ كان هناك

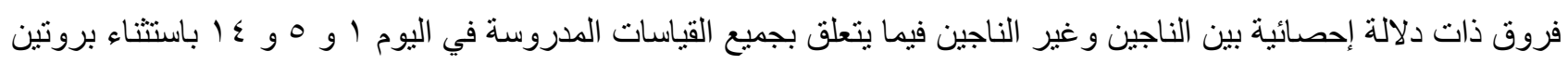
سي التفاعلي فقط كان في اليوم 0 و ـ ا لوحظ فرق إحصائي ـ كانت حساسية إنزيم الكولينستريز في البلازما عند قياسه بمفرده

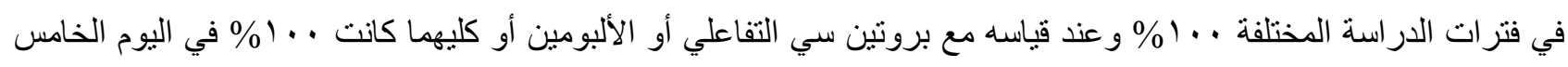
و الر ابع عشر.

ويستخلص من هذه الدراسة أن قياس كولينستريز البلازما يمكن أن يكون مؤشر تنبؤي بمفرده بحساسية .. ـ 1 في اليوم

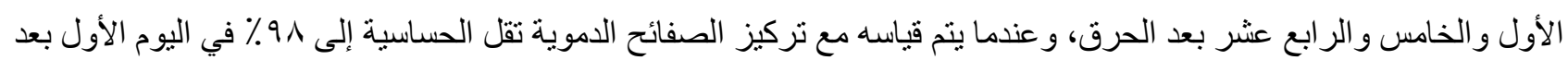

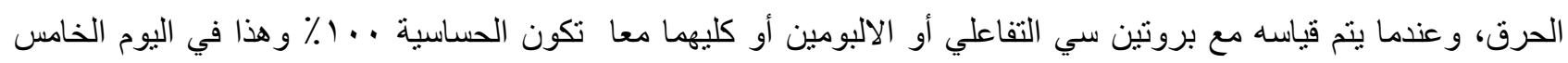
و الر ابع عثر.توصي هذه الدر اسة بإستخدام كولينستريز البلازما كمقياس معملي روتيني للمريض المصاب بحروق اليني حادة. 